\title{
De la transmissió de continguts a la socialització complexa
}

La crisi de la socialització de les creences religioses

\section{Jordi Collet i Sabé}

Universitat Autònoma de Barcelona. Departament de Sociologia jordi.collet@uab.es

\section{Resum}

La forta crisi de les institucions socialitzadores tradicionals (escola, família i Església) té el seu revers en la crisi dels processos de socialització tal com s'havien entès fins ara. En el camp de les creences religioses, hi podem veure com aquest procés evoluciona des d'una socialització tradicional que caracteritzem com a "transmissió de continguts», fins a les noves formes de socialització que agrupem sota l'adjectiu de complexa. Alhora, defensem en l'article que, en l'actual model de "socialització complexa» de les creences religioses, els elements afectius i relacionals són molt influents per comprendre'n el desenvolupament i els resultats.

Paraules clau: nous processos de socialització, creences religioses, identitats, afectes.

Abstract. From content transference to complex socialization the crisis of socialization of religious beliefs

The deep crisis of the traditional socializing institutions (school, family and church) has its counterpart in the crisis of the way socialization processes had been working up till now. Taking into account the area of religious beliefs, we can see how this process has evolved from the traditional socialization through «transmission of contents» up to the new ways of socialization, which could be labeled as complex. At the same time, the article suggests that the affective and relational elements, related to this model of "complex socialization» of religious beliefs, are quite influential to understand its development and outcome.

Key words: new processes of socialization, religious beliefs, identities, affections.

\section{Sumari}

\section{Introducció}

2. El context religiós actual

3. Una nova perspectiva del procés de socialització
4. El model d'anàlisi

5. Els quatre tipus ideals de transmissió i socialització de les creences

6. Conclusions 


\section{Introducció}

Segurament, la crisi més profunda per la qual pot passar qualsevol institució, cosmovisió o religió és la de la seva transmissió. Aquesta crisi esdevé un dubte radical sobre la seva pròpia identitat, sobre la seva pròpia plausibilitat, és a dir, sobre si té alguna mena de sentit que aquelles creences, aquella ordenació del món, aquell sentit, continuï existint en un context social determinat. D'alguna manera, aquesta és una de les preguntes més punyents que ressonen en el cor dels debats sobre la socialització de les noves generacions que es materialitzen en les crisis de l'escola, de la família i de l'església.

L'article que presentem, fet a partir de la recerca de doctorat ${ }^{1}$, està dividit en tres parts diferenciades. Una primera, que busca donar rellevància a alguns dels elements del procés de modernització que més influeixen sobre els processos de socialització de les creences religioses (modernització, secularització, pluralisme, desinstitucionalització i noves identitats). Una segona, que busca recollir els diferents qüestionaments al procés de socialització tal com s'ha entès tradicionalment des de la sociologia. I, finalment, una tercera i una quarta part, que mostren els resultats de la recerca en forma de quatre tipus ideals de processos de socialització que ens ajuden a comprendre l'evolució i la crisi del fenomen. Per concloure, esbossem un apartat de conclusions dels elements més significatius de la recerca.

\section{El context religiós actual}

En aquest primer apartat, analitzarem breument el context religiós actual i ho farem a partir de quatre grans eixos: el procés de modernització, del qual farem una breu caracterització; els processos de secularització i pluralisme; el procés de desinstitucionalització concretat en l'Església catòlica, i, finalment, els nous models identitaris relacionats amb les creences religioses.

\subsection{Algunes caracteristiques de la modernitat}

Podem identificar tres dels processos que han caracteritzat el procés de modernització i que ens proporcionen elements de context per a l'anàlisi del procés de socialització.

\subsubsection{Priorització de la racionalitat instrumental (Zweckrationalität)}

És a dir, de l'imperatiu d'adaptació coherent dels mitjans als fins que es persegueixen. Aquesta racionalitat va molt lligada al pensament científic, la tecnologia i la burocratització: entès com aquell pensament que racionalitza les «irracionalitats». Cal dir que, des de fa ja una colla d'anys, aquesta concepció «positiva» de la racionalitat com a «llum» que va il.luminant progressivament

1. Tesina amb el títol Els nous processos de socialització de les creences religioses. Sota la direcció del Dr. Joan Estruch. 
els espais «foscos» de la irracionalitat, i que ens portarà fins al progrés i la civilització total, ha estat molt problematitzada des de diferents àmbits. Per exemple, des de les aportacions dels pensadors postmoderns, ha estat molt criticada la «bondat» de la ideologia de la racionalitat i del progrés ${ }^{2}$; i també en la perspectiva de qüestionar «l'altra cara» i els efectes no previstos d'aquest «camí cap al progrés i la civilització guiat per la racionalitat» que ha estat la modernitat, podem trobar les interessants crítiques i qüestionaments globals de l'ecologia i la teoria de la societat del risc ${ }^{3}$.

Pel que fa a les creences religioses, si concretem aquest procés, trobem que també la religió catòlica s'havia convertit en un «gran metarelat» de la modernitat i, per tant, ara, també està fortament qüestionada. Allò que es posa en dubte és la seva voluntat omnicomprensiva i omniexplicativa, i el seu lligam amb el projecte il.lustrat, modern.

\subsubsection{El procés d'autonomització de l'individu (individualització)}

Que l'ha portat a ser cada vegada més subjecte, a ser capaç de «fer» el món en què viu i de construir ell mateix els significats que donen sentit a la seva pròpia existència. Aquest complex procés, entre d'altres, ha estat abordat per dues perspectives complementàries, la de Weber i la d'Elias.

Segons Weber, en el procés de modernització, es fa el pas de la preeminència de les "societats comunitàries» (Gemeinschaft) a les "societats societàries» (Gesellschaft). Aquest pas implica que cada vegada tenim més relacions socials "pactades» racionalment en funció d'interessos i de valors. Podríem dir que, en la modernitat, la majoria de les relacions socials estan "racionalment constituïdes" (serien les accions racionals d'acord amb els valors i les finalitats). Per contra, malgrat que no desapareguin pas, tenim menys relacions constituïdes sobre la base del sentiment de pertinença a un tot comú (comunitàries), és a dir, fonamentades en l'afectivitat, l'emotivitat i la tradició (accions emocionals o tradicionals).

Aquest procés d'individualització, d'autonomització de cada persona respecte a la «seva comunitat» on s'ha socialitzat, esdevé un dels trets més característics de la modernitat: les persones esdevenen legisladores de la seva pròpia vida, capaces igualment, en relació amb d'altres, de determinar les orientacions que creuen que han de donar al món que les envolta. Alhora, ens trobem amb la paradoxa que les persones, en aquest context plural, escullen, són més autònomes, més subjectes, però també són més fràgils (pel que fa a la identitat, les creences, les relacions socials, la feina, les pertinences, la ubicació terri-

2. Com a reculls interessants d'aquestes aportacions des de posicions crítiques, vegeu ANDERSON, P. (2000). Los origenes de la posmodernidad. Barcelona: Anagrama [1998]; o JAMESON, F. (1996). Teoría de la postmodernidad. Madrid: Trotta [1991].

3. Les aportacions fetes per U. Beck el 1986 sobre els riscos a la nostra societat, semblen un catàleg de prediccions que s'han anat acomplint. Dos llibres amb aportacions molt interessants sobre aquest tema són: BECK, U. (1998). La sociedad del riesgo. Barcelona: Paidós [1986], i també, AADD (1996). Las consecuencias perversas de la modernidad. Barcelona: Anthropos. 
torial, etc.) per la seva mateixa fragmentació ${ }^{4}$ i la contaminació cognitiva ${ }^{5}$, que porta a una crisi estructural de sentit. Així doncs, com ja hem apuntat abans, les nostres societats modernes (preeminentment societàries) tenen com a característiques pròpies la primacia de l'individu (sobre la comunitat) i un context de pluralisme (religiós, ètic, simbòlic, familiar, sexual, etc.) que deriva del reconeixement recíproc de les autonomies individuals.

$\mathrm{Si}$ concretem aquest eix del procés de modernització en relació amb les creences religioses, podem veure que té una gran importància. Aquest àmbit, el tractarem al final del capítol a partir de les aportacions d'Hervieu-Léger.

\subsubsection{La multipluralització dels mons de vida social \\ (la multipluralització dels mons donats per descomptat (Lebenswelt)}

Ser persona humana implica viure en un món, viure en una realitat que està ordenada i que dóna sentit a la vida. Aquest món, en bona part preexistent a nosaltres mateixos i amb el qual compartim els pressupòsits bàsics, allò donat per descomptat, allò que dota de sentit les nostres vides..., és el món de la vida quotidiana (o Lebenswelt). En el procés de modernització, cadascun d'aquests «mons», que tenia una certa unitat, una certa integralitat, s'ha anat complexificant, diversificant i pluralitzant. Això implica que la vida quotidiana de cada persona ja no està només en relació amb un o dos d'aquests mons, d'aquestes cosmovisions, d'aquestes «cultures». Avui en dia, cadascú de nosaltres, $\mathrm{i}$ especialment la gent jove, està en contacte permanent amb una pluralitat de mons, de Lebenswelt, de cosmovisions, molt gran. I, sovint, entre aquests diferents mons no hi ha cap mena de relació, és més, sovint estan en clara contradicció. Per això, creiem que podem parlar d'un multipluralisme de mons de la vida quotidiana en el qual es mou i viu la gent. És el que des d'altres aproximacions s'ha anomenat «la segmentació de l'experiència», "la fragmentació de la vida», etc.

Aquest procés de multipluralització de mons on cadascú de nosaltres viu, experimenta, treballa, es relaciona..., es dóna perquè la quantitat de cosmovisions i Lebenswelt ha augmentat i continua augmentant dia rere dia, amb la seva complexificació i diversitat corresponent. És a dir, la realitat social esdevé cada vegada més complexa, diversa i fragmentada perquè cada vegada hi ha més "mons», universos i cosmovisions que conviuen en el nostre espai social i perquè, dins de cadascun d'aquests, cada vegada és més complicat trobar «una versió» de la visió del món. A més, aquesta multipluralització «interna i externa» dels mons de vida, la podem trobar tant en l'esfera privada com en la pública.

4. Sobre la fragmentació del jo, vegeu GERGEN, K. (1991). El yo saturado. Barcelona: Paidós.

5. Aquest concepte implica ser conscient que les opcions que he triat són una opció més, contextualitzada i relativa. I que en podria haver triat, perfectament, unes altres. Altres autors parlen de contingència: en la modernitat tardana (o reflexiva), les persones estem en un context necessàriament contingent on ningú no es pot escapar, en paraules de Sartre, «de la condemna a ser lliure». 
Així, si concretem aquest procés en el tema de la religió, podem veure que les possibilitats que «una» creença doni sentit a tota la vida d'una persona (a totes les «vides») esdevé difícil. Per tant, tal com apunta Berger ${ }^{6}$, el més habitual de trobar és que cadascú, o en petits grups, es miri de "construir» i mantenir (de «bricolar») un «món domèstic» que pugui servir de centre significatiu i orientador de la vida de cadascú en aquest context multiplural, divers, complex i fragmentari de mons de vida. És la condemna sartriana «a ser lliures». Però aquesta opció és arriscada, precària i fràgil, ja que, en el nostre context, des dels primers anys de socialització ens trobem amb aquesta multipluralitat dels mons. I aquest fet té unes repercussions importants sobre el procés socialitzador i identitari de les persones.

\subsection{El procés de secularitzación}

Entendrem la secularització com el procés d'una societat a través del qual la religió i les institucions religioses deixen de tenir un paper clau en l'articulació de creences, en la definició dels valors dominants, en la preservació de la cohesió social i en la construcció de la identitat personal dels individus que la integren. Per tant, podem trobar, en una societat en procés de secularització, una creixent autonomització dels diferents àmbits d'aquesta respecte a les institucions religioses, així com una creixent autonomització de les persones (creients i no creients), que són reconegudes com a autònomes i capaces de decidir sobre el sentit i el valor de tots els elements de la seva vida. I, per tant, també en allò simbòlic, sagrat, religiós, moral, ètic, etc.

La secularització també implicaria, doncs, que la religió esdevé un tema fonamentalment ubicat en l'àmbit privat i una font cada vegada menys significativa a l'hora de prendre decisions d'ordre social i públic. La secularització, en contra de força interpretacions, no implica cap "crisi de creences»: ni de les creences religioses («societat descreguda»), ni en cap altre àmbit. El procés de secularització (cal remarcar que són processos oberts, dinàmics i diversos a cada lloc) implica, senzillament, que la religió i les institucions religioses deixen de «tutoritzar» la vida pública de les societats i que també deixen de ser $e l$ referent per a la construcció moral de les identitats personals, de les opinions, de les creences, etc. Així, les religions passen a ser una elecció més en el ventall de referents culturals, morals, ètics, axiomàtics i de creences de les persones i els grups socials. Per tant, una societat secularitzada com la nostra no és, en cap cas, una societat ${ }^{8}$ "que va cap a la desaparició de la religió a través d'un esquema evolutiu lineal, sinó una societat en la qual, al costat de formes d'expressió de la religiositat tradicional, apareixen formes noves».

6. Berger, P. L.; Berger, B. (1979). Un mundo sin hogar. Modernización y conciencia. Santander: Sal Terrae [1964].

7. Basat en Estruch, J. (1996). Secularització i pluralisme en la societat catalana d'avui. Barcelona: Institut d'Estudis Catalans.

8. EstruCH, J. (2003). La secularització. Ponència presentada al IV Congrés Català de Sociologia. 


\subsection{El pluralisme religiós}

El pluralisme religiós es dóna en les societats on coexisteixen sistemes de legitimació diversos, en igualtat de condicions, i sense que cap no pugui aspirar a tenir una condició hegemònica o de monopoli. Aquest concepte, a vegades s'aplica de manera automàtica com un afegit al procés de secularització. Però la seva concreció varia molt en funció de cada context i no es pot aplicar un mateix model de manera mecànica. Per exemple, a Catalunya, com assenyala Estruch ${ }^{9}$, el context de pluralisme ha passat i passa més per la possibilitat d'escollir davant l'opció majoritària, la catòlica, que no pas per l'emergència d'un «mercat religiós» a l'estil nord-americà. I fruit també d'aquest context específic, allò que adjectivaria d'una forma més pertinent el nostre pluralisme, podria ser un "pluralisme indiferent» acompanyat d'un analfabetisme de cultura religiosa creixent.

El segon aspecte que voldríem destacar sobre el pluralisme religiós, i ja més específicament en el context de les generacions més joves, és que, segons Griera i Urgell ${ }^{10}$, el que podríem trobar és un procés de no assimilació total de cap dels sistemes religiosos, sinó més aviat un majoritari coneixement difús sobre una diversitat important de tradicions religioses, sense que cap sigui aprehesa com a pròpia o com a fonamental. Alguns dels «nous» elements d'aquesta «nova cultura religiosa dels joves» que s'expressa en una notable diversitat de formes, idees i concrecions, els podríem trobar en aquests punts:

- Un discurs crític amb qualsevol pretensió de monopolització de l'univers religiós, i un discurs que «idolatra el pluralisme, la tolerància i l'heterogeneïtat» (almenys en el discurs)...

- Influències clares, alhora que poc estructurades, de les tradicions religioses orientals.

- Elements com ara la relació entre el cos, la ment, la salut i la medicina alternativa, en l'accepció més àmplia possible del terme, entren amb força en l'univers simbòlic i espiritual del jovent.

- Parlaríem d'un univers on el que és natural, ecològic, artesanal (per contraposició al que és artificial, dolent, destructiu) té capacitat per donar pau i benestar i, per tant, per «salvar».

Fent una explicació més general, podem dir que, a partir del procés d'individualització, es dóna una creixent autonomia de cadascú en el procés de dotació de sentits, significats i creences. I aquest procés d'individualització es dóna en un context de pluralisme de creences. Aquestes creences, que comencen a ser «alternatives» a l'opció catòlica que encara és la majoritària, no les hem d'interpretar com a lots tancats que «et quedes» sencers, sinó que les hem d'entendre com a materials diversos a partir dels quals cadascú es conforma el seu collage amb diversitat d'elements i de graus d'elaboració.

9. Estruch, J. (1996). Secularització i pluralisme en la societat catalana d'avui. Barcelona: Institut d'Estudis Catalans.

10. Griera, M.; URgell, F. (2002). Consumiendo religión. Nuevas formas de espiritualidad entre la población juvenil. Barcelona: Fundació La Caixa. 
Finalment, volem posar un punt crític a aquesta visió que de vegades esdevé una mica naïf de la diversitat, la pluralitat, etc. Tot i estar d'acord amb aquestes perspectives, també podem veure que en aquest mateix context es dóna la paradoxa que, com més individual i subjectiva és la tria de les creences, de les idees, de les identificacions, etc., també es dóna més homogeneïtat «de fons» en aquesta mateixa tria. Com diu Vidal ${ }^{11}$ "Hay una especie de agorafobia colectiva por cuanto se rechaza lo macrosocial, las grandes instituciones, los grandes proyectos. Esa macrofobia se corresponde con una intensa microfilia: es cierto que en nuestras sociedades de entre siglos cada vez hay una mayor profusión de libertades y diversidades en lo microcial, pero que perversamente se corresponde con una mayor solidez del pensamiento único en lo macrosocial (economía, política...)».

\subsection{El procés de desinstitucionalitzación ${ }^{12}$}

A continuació, doncs, tractarem el tercer dels grans eixos que hem apuntat per descriure el context religiós actual, després del procés de modernització i dels processos de secularització i pluralisme religiós. Aquesta aproximació la farem en dues parts: una primera que tracta de la desinstitucionalització com a procés general, i una segona que aborda aquest tema centrant-se en l'Església catòlica.

Tradicionalment, els manuals de sociologia afirmaven que la família, l'escola i l'Església eren institucions fonamentals per a la societat, que, juntament amb el treball, asseguraven la seva reproducció i la seva estabilitat i que "produien» persones «ben» socialitzades que podien funcionar en aquesta mateixa societat. Avui en dia, en paraules de Dubet i Martuccelli, «ninguna de estas instituciones funciona con el modelo clásico, como aparatos capaces de transformar los valores en normas, y las normas, en personalidades individuales. No se trata solamente de una "crisis" de las instituciones». Així, ens trobem davant un procés que anomenem "desinstitucionalització» i que té un abast força considerable. Com diuen els autors francesos: «la desinstitucionalización señala un movimiento profundo, una manera totalmente diferente de considerar las relaciones entre normas, valores y personas, es decir, una manera absolutamente diferente de concebir la socialización». Explicant una mica més el concepte, podem dir que es refereix al fet que els valors i les normes rebuts ja no són percebuts com a transcendents a les persones. Tot allò rebut és percebut com el que és: construccions i produccions socials, heterogènies i sovint contradictòries, fruit de diferents hàbits, interessos, lleis, polítiques i lluites, que desemboquen en equilibris, més o menys estables, a partir dels quals les persones construeixen les seves experiències i es construeixen a ells mateixos com a actors i com a subjectes.

11. Vidal, F. (2003). «Famílies joves a Europa», a FundaCió ClareT (2003). Famílies joves: El repte de viure i transmetre l'experiència cristiana. Barcelona: Claret, p. 31.

12. A partir de Dubet, F.; Martucelli, D. (2000). En qué sociedad vivimos. Buenos Aires: Losada [1998]. 
Per exemple, parlant de la família, podem dir que ja no és la institució la que «'s'imposa» sobre les persones, sinó que són aquestes les que escullen "construir o no construir» aquesta institució i la manera com ho fan. Així, les grans institucions (escola, família i Església) han perdut allò que constituïa la seva «essència»: la seva identificació amb principis generals i la seva capacitat de socialitzar individus a partir d'aquests principis. Per tant, els processos d'integració a la societat ja no es realitzen a través d'una "programació» estàndard i reglada que assegura la coordinació de les conductes.

\subsection{La desinstitucionalització a l'Església catòlica}

Si apliquem aquesta perspectiva a la institució catòlica, veiem que, segons els autors francesos ${ }^{13}$, «la declinación institucional de la iglesia [católica] corresponde al debilitamiento de su organización y de su influencia. Pero además se refiere también al agotamiento del perfil mismo de la institución, tal como lo muestra lo que en algunos casos está presentado como una renovación religiosa, organizando de manera novedosa las relaciones entre dogma y fe, sin beneficio para la iglesia». Aquesta tensió dins de l'Església entre un moviment més proper a l'obediència als dogmes i un moviment que opta més per l'expressió subjectiva de la fe, per la construcció autònoma del sentit, també correspon al perfil de desinstitucionalització, de debilitament institucional que apuntàvem abans.

Hi ha un procés de separació, una tensió important entre el dogma (com a expressió del model clàssic d'institució) i les creences (com a expressió del nou context on hi ha una subjectivació de les creences); hi ha un conflicte permanent d'interessos i tendències, alhora que les exigències d'autonomia, de reflexivitat, d'autenticitat, d'expressivitat i de tria de formes i continguts religiosos semblen irrenunciables per a tothom.

\subsection{Les noves identitats religioses}

Com ja hem comentat, el tret que podem considerar més característic de la modernitat tardana pel que fa al món de les creences, és la reivindicació i l'exercici massiu dels individus del dret de coordinar personalment els "petits» sistemes de significació que els permeten donar un sentit a la seva existència. I també l'exercici del dret d'escollir lliurement (si ho volen) les referències a les diferents tradicions o opcions per configurar la seva opció de creença.

La centralitat d'aquesta dinàmica de subjectivació de les creences va lligada a l'esfondrament massiu dels dispositius institucionals de transmissió de les creences que asseguraven la reproducció d'identitats religioses comunitàries, compactes, substancials i encaixades en identitats familiars, socials i locals estables. La modernitat religiosa es caracteritza per aquest doble moviment d'individualització i pluralització de les pràctiques religioses, i de les trajectòries 
d'identificació i de pertinença a línies creients. Podríem parlar, doncs, d'un "nou règim de veritat religiosa»: la "veritat subjectiva».

A aquest nou règim de «religiositat» ens hi podem aproximar a partir de les fórmules ben trobades del believing without belonging, és a dir, de la persona que creu, però que aquesta creença no està determinada, tutoritzada, per cap institució, ni per cap gran (meta)relat, ni per cap pertinença estable; i també la fórmula del belonging without believing, que representa tota aquella gent que «utilitza» la religió i les institucions religioses (a casa nostra, l'Església catòlica) en els moments de la vida en els quals li és útil (notablement rituals de pas), però sense que això vulgui dir que comparteix les creences, els dogmes, la moral, etc. expressades per aquella tradició religiosa.

En aquest context de «noves pertinences i noves pràctiques» en el camp de les creences, ens trobem amb una paradoxa ja esmentada: d'una banda, tenim cada vegada més autonomia decisòria sobre les nostres creences i les nostres pertinences, alhora que, i en la mateixa mesura, creixen les dificultats per viure en aquesta incertesa constant. I, per tant, les lògiques d'autonomització i de pluralisme tenen el seu revers en una lògica de desestabilització dels sentits, dels significats, de les creences $i$, per tant, de les identitats en general i de les religioses en el nostre cas.

En termes més coneguts, podem parlar $\mathrm{del}^{14}$ «socavamiento del conocimiento dado por supuesto a causa del pluralismo moderno. El mundo, la vida, la sociedad y la identidad personal son cada vez más problematizados». Els mons, els valors, les creences, les normes, les actituds donades per descomptat en base als quals les persones edificaven la seva vida, les pràctiques i els sentits, estan profundament i continuadament qüestionats per aquest multipluralisme i cadascú s'ha d'espavilar en el seu àmbit privat. A més, aquest qüestionament és especialment fort en tot l'àmbit religiós. La "crisi estructural de sentit», la relativització i la "descanonització» dels sistemes de creences i valors i dels esquemes d'interpretació de què parlen Berger i Luckmann són aplicables $\mathrm{amb}$ tota la seva cruesa a l'àmbit religiós. Així doncs, podem veure que tot l'espai social de les creences religioses és un espai que bull i és ben viu.

\section{Una nova perspectiva del procés de socialització}

A partir de les aportacions de Dubet ${ }^{15}$ i Willis ${ }^{16}$, volem fer una reflexió que se centra en la manera com es dóna avui en dia el procés de socialització. Com

14. Berger, P.; Luckmann, T. (1997). Modernidad, pluralismo y crisis de sentido. Barcelona: Paidós.

15. Les idees d'aquest autor les traiem de DuBET, F. (1994). Sociologie de l'expérience. París: Seuil; i DUBET, F. (2000). «La formation des individus: la désinstitutionalisation», a AADD (2000). Jeunesse et société: La socialisation des jeunes dans un monde en mutation. Brussel-les: De Boek.

16. Les idees d'aquest autor, les traiem sobretot de tres fonts: WILLIS, P. (1998). Cultura viva. Barcelona: Diputació de Barcelona [1990]; WILLIS, P. (1981). «Producción cultural no es lo mismo que reproducción cultural», a AADD (ed.) (1993). Lecturas de antropología para educadores. Madrid: Trotta, i WiLlis, P. (1988). Aprendiendo a trabajar. Madrid: Akal. 
hem vist, la sociologia ha distingit i distingeix entre la socialització primària i la secundària. Aquesta és una diferenciació fonamental a l'hora d'abordar temes com ara la identitat, els rols, les opcions vitals, el paper de les institucions i els agents socialitzadors etc. Però aquesta diferenciació, creiem que està trontollant en els darrers anys. Així, pensem que estem davant un procés creixent de dissolució de les fronteres tradicionals entre la socialització primària i la secundària. I aquest procés de dissolució de les fronteres entre totes dues ens porta a una situació ambivalent en què cal replantejar-nos els conceptes, les etapes, les característiques i les relacions dins d'aquest gran procés que anomenem "socialització». Des de la tradició sociològica clàssica, podríem entendre que la socialització primària té diferents característiques bàsiques:

- L'etapa en la qual es dóna és la infantesa, tradicionalment entesa com l'etapa dels 0 fins aproximadament als 10 a 12 anys, quan comença l'adolescència.

- L'assimilació per part de l'infant del món dels adults com el món, com l'únic real.

— L'entorn on es dóna és la família i els pares esdevenen els «altres significatius».

- I, finalment, el procés es realitza en un marc afectiu.

Per contra, les característiques de la socialització secundària, serien:

- Que es dóna en persones adolescents i joves.

- Que en aquest procés es participa de diversos mons socials específics que tenen repercussió en aspectes parcials de la persona.

- Que no es dóna necessàriament en un clima afectiu.

— I que els agents socialitzadors són «altres generalitzats».

Pensem que, avui en dia, els processos de socialització dels infants (de $0 \mathrm{a}$ 12 anys) es donen en uns paràmetres diferents dels plantejats per la teoria de la socialització primària tradicional. Així, algunes de les característiques que fan «trontollar» el model tradicional i que ens podrien portar a parlar d'una «nova socialització primària» serien:

a) L'etapa en la qual se socialitza és la infancia. Malgrat que aquesta continua essent el marc vital del procés, cal analitzar com ha canviat la seva concepció social, els seus «usos» i la seva manera de ser «exercida», així com les seves «fronteres» amb l'adolescència.

b) Els infants, cada vegada des de més petits (potser des dels 4 a 5 anys), ja no assimilen el món dels pares com el món inqüestionat. Perquè des de ben petits ja conviuen amb una pluralitat d'adults significatius (pare, mare, possibilitat de diverses parelles de tots dos, altres familiars, diverses mestres de l'escola bressol que cada dia els atenen des de més petits, mestres d'educació infantil, possibles cangurs, monitors de menjador, d'activitats extraescolars, d'esplais, etc.); i també diversitat de companys i companyes 
(de diverses cultures, tradicions religioses, edats, etc.); així com també amb una pluralitat d'altres agents socialitzadors que poden ser significatius (notablement, la televisió o altres mitjans de comunicació). Tota aquesta pluralitat, que ja havia existit en el context de la família extensa, s'ha multiplicat i s'ha diversificat i fa que els diversos mons coneguts esdevinguin irreductibles a un. Pensem que, des la infancia, ja no se socialitza (o se socialitzen) els infants en un món, sinó que la pluralitat de mons, de valors, d'actituds, etc. té repercussions en la vida dels infants cada vegada des de més petits.

c) I això implica quelcom central: ja no hi ha cap institució socialitzadora, notablement la família, però tampoc l'escola o l'Església, que esdevingui el referent en un àmbit de la vida de l'infant de forma natural, per se. Es a dir, que en aquest context de pluralitat de mons des de la petita infancia, la família o l'escola no són de manera òbvia les institucions que donen pautes significatives en els diferents camps de l'infant: joc, identitat, sexualitat, actituds, valors, normes, etc.; sinó que cada espai socialitzador ha de "guanyar-se» la possibilitat de ser el referent significatiu en aquell àmbit concret, tot i saber que l'infant tindrà, molt probablement, altres referents.

d) Com dèiem, fins ara, semblava que només, o fonamentalment, es donava la socialització primària en el context familiar. Pensem que això s'ha trencat. La socialització primària de les criatures, des de la petita infancia, ja es dóna en molts casos en una pluralitat d'espais. I en aquests espais, «l'exclusiva» que tenien les mares i els pares d'esdevenir els «altres significatius» per excel.lència, ha perdut la seva «naturalitat». Per als infants, ja des de ben petits, pensem que es dóna una pluralitat «d'altres significatius» i que el grau i la importància de cadascun d'aquests ja no és donat per la institució que representen (família o escola), sinó per les seves actuacions amb els nens i nenes.

e) També vèiem que la socialització primària es donava en un marc d'afectivitat que era el possibilitador i un dels seus eixos centrals. Avui també aquest eix s'ha transformat a partir d'un doble moviment. D'una banda, la família, que era el "context afectiu» tradicional, es troba cada vegada amb més dificultats per exercir aquesta afectivitat amb els infants. I des de fa uns quants anys, s'ha anat "problematitzant» aquesta dimensió que abans era «òbvia». També cal tenir en compte, en el nou context, les creixents dificultats que té la família per exercir el seu paper socialitzador. Una família que pateix fortes tensions (relacionals, afectives, laborals, de conciliació d'horaris, etc.), que poden derivar en alguns casos en delegacions o fins i tot desercions d'aquesta tasca socialitzadora, per diversitat de motius.

f) Paradoxalment, les altres institucions socialitzadores, com ara l'escola i l'Església, partien d'una realitat on l'afectivitat era vista com un element negatiu i, en el cas de l'Església, fins i tot perillós. En canvi, en els darrers anys, aquestes dues institucions han anat adoptant el clima afectiu, les relacions interpersonals, l'atenció a l'emoció, etc. com un eix fonamental per poder continuar la seva tasca socialitzadora en fort qüestionament. Per exemple, l'escola ha adoptat moltes metodologies d'educació no formal, els pro- 
grames d'alfabetització socioemocional i, darrerament, la mediació, amb una forta càrrega de treball sobre les emocions i els sentiments, amb l'objectiu bàsic de poder continuar exercint la seva tasca socialitzadora i transmissora de coneixements. Per tant, veiem que també aquesta característica de la socialització primària, l'afectivitat, entra en «crisi» en el seu marc tradicional, la família, i es comença a treballar de forma clara en les institucions que tradicionalment no l'havien tingut en compte.

Resumint el que hem dit, pensem que caldria aprofundir en dues «intuïcions». D'una banda, hi ha una dissolució de les especificitats de la socialització primària i secundària, la qual cosa dóna lloc a un «nou» escenari que podem anomenar «socialització complexa». Així, la perspectiva de la socialització complexa contemplaria més aviat aquest procés com un continu des del naixement de l'infant fins a la seva adultesa, sense que en les característiques i els elements de la seva socialització hi hagués cap trencament clar entre una primera i una segona socialització. En aquest nou continu, hi podem trobar un doble moviment. D'una banda, les característiques que es van imposant cada vegada més aviat en el procés socialitzador corresponen sobretot als elements que tradicionalment ubicàvem en la socialització secundària. Però, d'altra banda, un dels elements centrals de la primària, l'afectivitat, està en crisi en la institució que tradicionalment l'havia exercida i comença a ser valorada en les institucions que no l'havien "practicada» tradicionalment.

\section{El model d'anàlisi}

Partint d'aquestes intuïcions, vam buscar la manera de categoritzar aquests canvis i convertir-los en un model d'anàlisi per als processos actuals de socialització de les creences religioses. Així, podem veure que en el model hi ha dos eixos, el què i el com: el contingut i les metodologies. A partir d'aquest model d'anàlisi, ens apareixen quatre tipus ideals de socialització de les creences. Cal tenir clar que aquests no existeixen en la realitat, sinó que aquestes tipologies intenten ser un instrument per classificar, identificar i repensar tendències i processos en els models de transmissió de les creences.

\subsection{Els conceptes}

Els conceptes centrals del model d'anàlisi són els quatre punts cardinals d'aquest a partir dels quals sorgeixen els quatre tipus ideals de procés de transmissió de les creences.

\subsubsection{La socialització "clàssica»: la transmissió}

El primer dels pols del model que abordem és el model de socialització que hem definit com a "clàssic» i que anomenarem transmissió. Aquest model és unidireccional, l'agent transmissor «en sap» i transmet «un bloc tancat» d'actituds, valors, normes i coneixements o d'experiències a les noves generacions. 


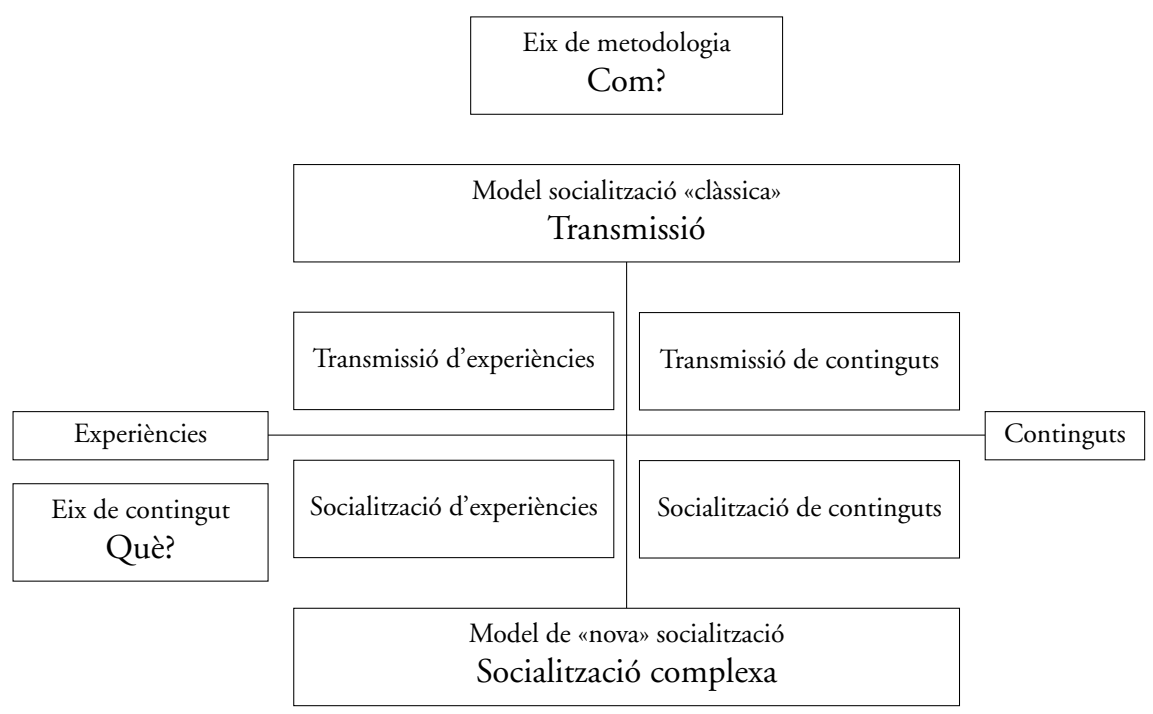

En el model de la transmissió, de la inculcació, no hi tenen gaire cabuda ni la reflexivitat, ni el diàleg en un pla d'igualtat, i el «resultat» del procés de transmissió en els adolescents i en els joves hauria de ser la seva adaptació a l'entorn social a partir de l'aprenentatge passiu dels elements que se li transmeten. La part important és la dimensió objectiva del que transmetem i no tant la subjectivitat de qui ho rep. D'alguna manera, estaríem parlant del que Freire anomenava "educació bancària» ${ }^{17}$. Freire la defineix en una relació on «'educador» (el transmissor) sempre educa, és qui sap, qui pensa, qui parla, qui disciplina, qui opta, qui actua, qui escull els "continguts», qui és el subjecte del procés. I on «l'educand» (el transmès) és educat, no sap, no pensa, escolta, és disciplinat, compleix ordres, s'acomoda al «programa» que diu l'educador i és l'objecte del procés.

$\mathrm{Si}$ apliquem el model de transmissió al tema de les creences religioses, creiem que podríem dir que l'objectiu del model és agafar el que s'ha rebut, sobretot institucionalment, i passar-ho "com un bloc», com una herència que s'agafa o que es deixa, a les noves generacions per mitjà de l'estudi, el coneixement explícit i el treball fonamentalment intel.lectual i racional. Sobre aquesta darrera característica, pensem que en el model de transmissió la valorització de la racionalitat és positiva, mentre que la valorització de tot el món afectiu i emotiu és negativa. Finalment, l'avaluació dels «resultats» d'aquest procés la podríem situar en el "grau de conformitat creient» ${ }^{18}$ dels infants, adolescents i joves en relació amb les creences, els coneixements, els valors, etc. que els han transmès

17. Freire, P. (1987). L'educació com a pràctica de llibertat. Vic: Eumo, p. 47 del pròleg).

18. Hérvieu-Léger, D. (1999). Le pèlerin et le converti: La religion en mouvement. París: Flammarion, p. 64. 
(la família, l'Església, l'escola, etc.). O, dit d'una altra manera, en el grau de conformitat a l'ortodòxia. És a dir, avaluant l'adequació d'allò que un creu a allò que cal creure i que és manat com a digne de ser cregut. Cal recordar que aquest és el model de partida, el referent, el que havia estat hegemònic, tot i que ara deu ser segurament poc utilitzat. A partir d'aquest, han aparegut els altres tres models, que en són una evolució.

\subsubsection{La «nova» socialització: la socialització complexa}

La descripció del model de socialització busca comprendre quines són les tendències que marquen la pauta del que nosaltres pensem que esdevé un nou «model ideal» de socialització.

a) D'entrada, cal dir que el model de socialització complexa comença per la seva oposició al model de transmissió, però va més enllà. La dimensió «d'estranyesa del subjecte» introdueix, en el model de la «nova» socialització, una dimensió de complexitat de lògiques i d'interacció entre elles. Quan pensem com es dóna el procés de socialització d'un noi o d'una noia adolescent o d'un jove o una jove avui dia, podem veure que la quantitat de «mons», de perspectives, d'opcions vitals, d'opinions, d'inputs dels mitjans de comunicació de massa, etc. que haurà conegut, i que converteixen en poc pertinent qualsevol intent de voler donar a un d'aquests mons, sigui el de les creences o qualsevol altre, un sentit de necessitat: tots els mons comparteixen contingència, relativitat i dubte.

b) D'altra banda, podem veure que la reflexivitat és al cor del model de socialització complexa. I és precisament la reflexivitat un dels «eixos» centrals que marca la construcció de la subjectivitat i de la identitat de cadascun dels adolescents $\mathrm{i}$ joves, amb tot el que això comporta d'autonomia i de fragilitat permanent.

c) Lligat al tema de la identitat, arribem al paper de l'afectivitat en el model de "nova» socialització. Si dèiem que la racionalitat era positiva en el model de transmissió i que, per contra, tot allò referent a l'afectivitat i els sentiments era considerat negatiu, pensem que precisament en el model de socialització complexa es dóna una realitat inversa. Tot allò referent a l'afectivitat esdevé central en aquest procés de construcció de la subjectivitat, perquè esdevé «el motor» a partir del qual els adolescents i joves es mouen per la xarxa social, cercant els diferents nodes, les diferents tribus en les quals puguin «estar junts», amb les quals puguin identificar-se, segons el model de Maffesoli. Des d'altres disciplines socials, també des dels darrers anys, s'està posant molt d'èmfasi en el paper de l'afectivitat i les emocions en la descripció del desenvolupament dels processos socials i cognitius. Per exemple, des de la psicologia, l'anomenada «intel-ligència emocional» és definida com «una manera d'interactuar amb el món que té molt en compte l'afectivitat i les emocions i que engloba diverses habilitats personals i socials» ${ }^{19}$.

19. Goleman, D. (2002). Intel-ligència emocional. Barcelona: Kairós [1995], pròleg. 
Sobretot pel que fa als adolescents i als joves al llarg del seu procés de socialització (complex), des de les ciències socials, ens estem adonant que la seva «alfabetització afectiva i emocional» constitueix una de les claus de volta per tal que pugui tenir lloc aquest procés amb resultats positius.

d) El darrer aspecte que volem destacar del model de socialització «complexa» és la centralitat de la vida quotidiana (Lebenswelt). Sovint, en diferents àmbits transmissors, «l'espai» triat com a destinatari per fer aquesta transmissió era la consciència, la voluntat, la racionalitat, etc. Per contra, en el model de socialització complexa que proposem, «el lloc» alhora possibilitador i «destinatari» de la socialització és el món de la vida quotidiana, pres com a globalitat. És aquest món l'espai significatiu per excel-lència.

Si intentem "aplicar» aquest model de socialització complexa al tema de les creences religioses, trobaríem que no hi ha tant uns continguts clars, delimitats, intel.lectuals, «un bloc» que cal transmetre, i el paper dels «educadors» tampoc no ens remet al model de transmissió. La reflexivitat compartida sobre les creences entre "educadors i educands" en el Lebenswelt esdevé el nucli del model, tenint en compte sobretot el paper de les creences en el procés de construcció de la subjectivitat i de la identitat, alhora valorant els aspectes afectius d'aquest procés d'una forma positiva, i veient com a "normals» els dubtes i les relativitzacions sorgits de l'estranyesa del subjecte.

Si el volguéssim avaluar, caldria prendre com a objecte el procés de construcció de la subjectivitat, el grau d'autonomia i la capacitat de reflexió i empatia de cadascú. I estaríem a les antípodes de l'avaluació formal sobre continguts tancats i predefinits que cal haver «après» com es dóna en el model de transmissió, o del model quantitatiu que vol saber el nombre de persones que van a missa. En aquest model, es posarien en qüiestió les tipologies «clàssiques» de creients i no creients, practicants i no practicants, etc., perquè, en un context on ja l'Església catòlica no és el punt de referència per a les creences i les pràctiques, aquestes categories per si mateixes no voldrien dir res. Així doncs, caldria explicitar en què i com es creu, què i com es practica, etc. en una «avaluació» més aviat autoreferenciada en cadascú i cada grup creient i no en una ortodòxia «objectiva» ${ }^{20}$.

\subsubsection{Les experiències}

Aquí ja abordem el segon dels eixos del model d'anàlisi: experiències i continguts. Així doncs, l'experiència seria «l'activitat» de construir la realitat, la pròpia subjectivitat a partir dels recursos que hom té: és a dir, l'activitat afectiva i reflexiva, personal i col-lectiva, de dotar de sentit la pròpia vida i les pròpies accions, valors, idees, creences, pràctiques i significacions. I també l'activitat social d'experimentar el que hem anomenat «l'estranyesa d'un mateix» $\mathrm{i}$ gestionar aquesta situació. L'experiència no implica la negació dels continguts,

20. Estruch, J. (2003). La secularització. Ponència presentada al IV Congrés de Sociologia de Catalunya. 
sinó que aquests tenen valor en funció de l'ús subjectiu que en pugui fer cadascú, no en si mateixos.

Si volguéssim aplicar-ho a contextos de socialització o transmissió de les creences, parlaríem d'experiència com el model de relacions socials globals quotidianes en la qual la relació entre «educadors i educands» no es basaria en cap contingut predefinit i tancat que caldria «impartir». El punt de partença de l'experiència com a "contingut» seria el mateix procés compartit de construcció de la subjectivitat, de les opcions, de les creences, dels valors i dels sentits de cadascú. És a dir, el punt de partença i d'arribada de les experiències serien la vida i el paper global de les creences religioses en l'existència de cadascuna de les persones implicades en el procés de socialització de les creences.

L'avaluació d'aquest «contingut» només podria venir donat per la valoració subjectiva dels participants d'aquest procés. Aquests, en funció de com valoressin aquestes experiències que s'ha anat construint en cadascú i en comú, donarien la seva opinió sobre el resultat de l'experiència viscuda i construïda.

\subsubsection{El contingut}

El contingut seria el pol oposat a l'experiència. El podríem definir com quelcom previ a qualsevol interacció social, que ja tenim "preparat» per transmetre: «un lot» que pot incloure valors, actituds, valors, normes, coneixements, etc., que volem que els nostres "educands» adquireixin com a tal. El contingut és important per si mateix, més enllà de la rebuda i de l'ús subjectiu d'aquest, que és el que caracteritza l'experiència.

Parlant del contingut relacionat amb temes de creences, entendríem aquest com a cos doctrinal, moral, legal, litúrgic, sacramental, com a ens «ja fet», ja donat, que cal transmetre a les noves generacions. El contingut és fonamentalment intel.lectual i racional. I si parléssim d'avaluar la transmissió o la socialització d'aquest contingut, caldria fer una comparació entre allò que ens havíem proposat «donar» als «educands» i què és el que han acabat «adquirint» respecte al conjunt global que es pretenia assolir. Per tant, estem davant la possibilitat de fer una avaluació més objectivable, ja que disposa d'uns «materials» objectius que poden donar raó de la mesura en què s'han adquirit.

\section{Els quatre tipus ideals de transmissió i socialització de les creences}

Així doncs, una vegada descrits els quatre conceptes que marquen la tensió dels dos eixos del model d'anàlisi, veurem quin és el resultat de la seva combinació. Com hem pogut veure en la representació gràfica del model d'anàlisi, ens apareixen quatre tipus ideals de transmissió i socialització de les creences, que intentarem aprofundir en aquest apartat.

Cadascun dels quatre tipus ideals — transmissió de continguts, transmissió d'experiència, socialització de continguts i socialització d'experiència- és un «model pur» que en la realitat no es dóna mai. Sempre que es concreta el procés de transmissió i socialització de les creences, hi ha una barreja d'elements dels diferents models. Per tant, estem parlant més d'una qüestió d'accents que 
no pas de diferències radicals en la realitat. Però el que busquen aquests models és simplificar la realitat sempre complexa i plena de matisos, amb la voluntat de comprendre-la millor. Aquest és l'envit de l'exercici.

\subsection{Model de transmissió de continguts}

Una primera aproximació al model de transmissió de continguts aplicat al camp de les creences es podria fer a partir del model didàctic clàssic, on trobem educador, educand i continguts. D'alguna manera, les creences, com a cos doctrinal, intel-lectual i racional, ja són donades institucionalment i continuen el seu camí unidireccional i immutable cap a les noves generacions. Seria com proposar, en un model «d'educació bancària» com el que hem descrit, que els adolescents i els joves incorporin, interioritzin, un lot força tancat, un «dipòsit» amb unes idees, uns models, uns comportaments, unes perspectives, unes actituds, uns sabers, unes pràctiques, uns valors i unes normes, etc., ja fets i sobre els quals hi ha poc per discutir.

En aquest model de transmissió de continguts, aquesta no problematització d'allò que cal transmetre és donada per la legitimitat de la institució que els proporciona, en aquest cas, l'Església catòlica. I en el mateix model podem dir que les creences poden acabar essent un àmbit finit de significació, un «lloc» separat del món de la vida quotidiana, al qual vaig fent «excursions» cada vegada que toca: rituals, formació, etc., però que queda lluny del que és significatiu per a mi, del que es mou en el meu Lebenswelt, en el meu món quotidià.

L'avaluació de «l'efectivitat» d'aquest model partiria del "grau de conformitat» amb les creences transmeses (ortodòxia), dels adolescents i joves. Seria com agafar una mesura de tot el que caldria que haguessin interioritzat i sabut i veure fins on ha arribat cadascú a diferents nivells: pràctiques, opinions, valors i normes, coneixements intel.lectuals, etc.

\subsection{Model de transmissió d'experiències}

La concreció d'aquest model a nivell de creences és complex, perquè, d'entrada, pot semblar que els conceptes de transmissió i d'experiències, enteses com a "contingut", són dos pols antagònics del model d'anàlisi. Malgrat això, creiem que aquest model també respon a realitats que podem trobar.

El model de transmissió d'experiències seria aquell en què els «socialitzadors» substitueixen un contingut tancat i racional, «un bloc» rebut institucionalment per aquelles experiències de construcció de la subjectivitat que han tingut ells o elles o que coneixen. Així doncs, en lloc de transmetre un «cos doctrinal», transmeten experiència: és a dir, la manera com jo o nosaltres («educadors») hem construït la nostra subjectivitat, les nostres creences, els nostres valors, les nostres pràctiques, etc. i ho transmetem com a bloc, en el marc del model de transmissió que hem descrit. Com dèiem al principi, pot semblar contradictori el fet de voler transmetre la pròpia experiència com a «cos doctrinal», com a creences, pràctiques i opcions tancades. Però pensem que també 
aquesta manera de fer la podem trobar en moltes de les interaccions de transmissió de les creences.

Si parlem de com es podria avaluar l'efectivitat d'aquest model, creiem que també cal recórrer al model de transmissió: a partir "del grau de conformitat creient» dels que han estat «transmesos». Però, en aquest cas, la «mesura» no estaria en els continguts donats per la institució, sinó en la pròpia experiència feta regla, constituïda en el model a partir del qual caldrà avaluar les creences, les pràctiques, els valors, etc. dels adolescents i joves.

\subsection{Model de socialització complexa de continguts}

En aquest tercer model ideal, canviem de quadrant per anar al de socialització de continguts. Aquest model també ens apareix en forta tensió entre el què (contingut) i el com (socialització complexa). Però també pensem, com en el model anterior, que les seves realitats també les podem trobar en la pràctica quotidiana de la socialització de creences catòliques. En el model resultant trobem que, d'una banda, tenim la reflexivitat, l'afectivitat i la vida quotidiana al cor de la metodologia de la socialització complexa; però l'objecte que es vol «transmetre» és, sobretot, un cos doctrinal, un bloc, unes creences, uns coneixements, una moral, uns valors i unes normes, etc. ja predefinits per la institució a partir de la qual es dóna el procés. Per tant, estaríem en un model explícitament reflexiu, on l'afectivitat i l'emotivitat tenen un paper central i on l'aplicabilitat de les creences en la pràctica i en la vida quotidiana esdevé el «mètode d'avaluació». Però, alhora, les creences que es pretenen socialitzar són una herència poc qüestionada, ja donada, i que s'accepta o no en la seva major part, però que no es pot estar qüestionant permanentment.

Com ja hem dit, possiblement l'avaluació de l'efectivitat d'aquest model seria determinada per la visibilitat i el grau «d'aplicació» dels continguts, del cos doctrinal, de la moral, dels valors, de les pràctiques, etc. a la vida quotidiana de les persones que han estat socialitzades en aquest model.

\subsection{Model de socialització complexa d'experiències}

Finalment, el model de socialització complexa d'experiències seria el que estaria a les antípodes del primer que hem presentat, el de transmissió de continguts. Aquest model de socialització complexa es basaria en una metodologia de socialització de les creences on no trobem un «cos doctrinal» predefinit que ens és donat per la institució, sinó que, més aviat, a partir de la reflexivitat, tenint molt en compte els aspectes relacionals i afectius, i tenint sempre com a punt de "partença i d'arribada» la vida quotidiana, es proposa com a objectiu la construcció personal i col-lectiva de la subjectivitat, de l'experiència i de les pràctiques de cadascuna de les persones que participa en el procés. És a dir, el què, el «contingut» del model de socialització complexa d'experiències seria el propi procés, personal i col-lectiu, de construcció de la subjectivitat, de les opcions, de les creences, dels valors, dels sentits, de les pràctiques, etc., a partir de la reflexivitat, 
en un context de valorització de l'afectivitat i les relacions personals i centrat en la vida quotidiana de cadascuna de les persones que participa en el procés. Aquesta vida quotidiana estaria presa globalment i les creences esdevindrien un element que podria «infusionar» totes les altres esferes i espais socials.

$\mathrm{Val}$ a dir que aquest model, sobretot si el comparem amb els altres, exposa importants dubtes sobre com es pot avaluar la seva efectivitat. Si no hi ha uns continguts clars i explícits, tampoc no hi pot haver cap avaluació que compti amb ells com a mesura. Per tant, si el punt de referència no són continguts (tant si es tracta d'un "cos doctrinal» que aporta la institució com «experiències personals» objectivades), ens trobem amb una avaluació de l'efectivitat del procés de socialització complexa de l'experiència que es mou en termes nous i diferents. Així doncs, l'únic punt de referència seria l'avaluació subjectiva que poguessin fer els participants del procés de socialització, respecte a la «utilitat» del propi procés i de les creences socialitzades i experimentades. Utilitat referida a la "tasca» de construcció de la seva subjectivitat, de les seves opinions, opcions, pràctiques i sentits, és a dir, utilitat pel que fa a la seva existència, entesa globalment.

\section{Conclusions}

Arribem al darrer punt de l'article, que busca destacar alguns dels elements més significatius que hi hem anat exposant.

\subsection{La crisi del model de transmissió de les creences}

a) La primera de les conclusions que volem exposar és la profunda crisi del model de transmissió de les creences que havia estat imperant a casa nostra i el seu accelerat procés de substitució per altres models no tan definits, ni «acabats». Aquesta transició accelerada comporta certa desorientació i certes tensions, $\mathrm{i}$ alhora també un procés d'intensa cerca de noves vies, a partir de diferents elements que nosaltres hem agrupat en el model de socialització complexa.

b) La crisi dels models de transmissió de creences i la seva creixent substitució pels models de socialització complexa esdevé alhora la crisi d'un model d'identitat cristiana fruit, fonamentalment, de l'època franquista. Així, la identitat cristiana de les persones que van viure el seu procés de socialització al llarg del franquisme és difícilment reproduïble en el context actual. Per tant, la crisi de la identitat cristiana que implicava el model de transmissió de les creences deixa pas a una incertesa sobre quines són les identitats cristianes en base a les quals es vol socialitzar les noves generacions. Així, els adults que havien estat «transmesos» $\mathrm{i}$ tenien una identitat creient d'acord $\mathrm{amb}$ aquest model, ara viuen una contradicció. Actualment es troben amb una identitat més o menys fruit del model de transmissió, però, alhora, han d'intentar socialitzar les noves generacions des d'un context, el de la socialització complexa, amb un model d'identitat cristiana en (re)construcció constant $\mathrm{i}$ amb referents clarament diferents dels propis. 


\subsection{La generalització del model de socialització complexa}

a) Amb la construcció del model de socialització complexa, hem intentat reunir i ordenar el què i el com de les «noves» maneres de socialitzar les creences. Així, n'hem destacat els elements de complexitat i diversitat, per fer paleses les dificultats que implica socialitzar (en el camp de les creences o també el de la família o l'escola, etc.) en un context de multipluralització de mons, de perspectives, d'opcions vitals, etc. i les conseqüències que d'això en deriven. També hem destacat que la reflexivitat és al cor d'aquest model i que, parlant sobretot de la socialització secundària, ja res no és "natural», donat per descomptat. Actualment, ens trobem amb la consegüent llibertat, d'una banda, i la fragilitat de la pròpia identitat, de l'altra. També hem vist que el paper de l'afectivitat i de les relacions personals eren centrals en aquest context. És el que ja hem vist amb Hervieu-Léger sobre la subjectivació de creure i de la importància dels testimonis de sentit per davant de les directrius institucionals. Finalment, hem destacat la centralitat de la vida quotidiana, del Lebenswelt, com a punt de partida i d'arribada d'aquest nou model de socialització.

b) També hem vist que, dins d'aquest model de socialització complexa, podíem veure dos tipus ideals de socialització: la socialització complexa de continguts i la d'experiències. Aquestes dues perspectives es diferencien entre si en funció del «contingut» (el què) que s'implementava en el procés de socialització complexa (el com). Així, hem proposat que el resultat de la socialització de continguts és la "creença objecte», que l'entenem com un estoc de creences que esdevenen un objecte, un cos doctrinal i moral significatiu, entès racionalment i que posseeixo. Per contra, el resultat de la socialització d'experiències, l'entenem més com la construcció d'un marc cognitiu, afectiu i epistemològic que m'orienta en el meu «navegar» en la vida i en la societat xarxa. En aquest «marc» (la «brúixola»), les creences esdevenen alhora els criteris d'orientació (finalitats) i sobretot de navegació (com faig les coses) a partir dels quals em guio i visc.

b) Finalment, hem fet un apunt sobre la profunditat d'aquesta evolució cap a la socialització complexa. Aquests canvis porten a una dissolució i a una ambivalència dels paràmetres, les etapes i els conceptes que s'utilitzaven per analitzar el procés de socialització.

\subsection{El rol de l'afectivitat en la socialització complexa}

a) En un context com l'actual de forta desinstitucionalització, de complexificació i de diversificació de l'estructura social i de les identitats i de reflexivitat creixent que pot arribar a ser angoixant, creiem que el paper de l'afectivitat és cada vegada més rellevant en el procés i en els resultats del procés de socialització.

b) Això és així per un doble moviment paradoxal que ja hem comentat. D'entrada, la institució en la qual l'afectivitat s'havia tingut en compte de 
forma "natural», la família, pels canvis i les pressions que hem descrit, comença a tenir serioses dificultats per continuar mantenint aquest rol «d'acompanyant significatiu i afectiu» dels infants, i sobretot dels adolescents i joves. Alhora, les institucions on l'afectivitat era vista més aviat com una «debilitat» o com quelcom antiracional, si no perillós, és a dir, l'escola i notablement l'Església catòlica, continuen fent passos per incorporar aquesta dimensió en els seus processos de socialització, perquè veuen que, sense l'afectivitat i tot el que implica, esdevé impossible dur a terme aquest procés.

\section{Bibliografia}

AADD (1996). Las consecuencias perversas de la modernidad. Barcelona: Anthropos. ANDERSON, P. (2000). Los orígenes de la posmodernidad. Barcelona: Anagrama (1998). BECK, U. (1998). La sociedad del riesgo. Barcelona: Paidós (1986).

Berger, P. L.; BERGER, B. (1979). Un mundo sin hogar. Modernización y conciencia. Santander: Sal Terrae (1964).

Berger, P.; LuCKMAnN, T. (1997). Modernidad, pluralismo y crisis de sentido. Barcelona: Paidós.

Dubet, F.; Martucelli, D. (2000). En qué sociedad vivimos. Buenos Aires: Losada (1998).

Dubet, F. (1994). Sociologie de l'expérience. París: Seuil.

- (2000). «La formation des individus: la désinstitutionalisation», a AADD (2000). Jeunesse et société. La socialisation des jeunes dans un monde en mutation. Brussel.les: De Boek.

EsTRUCH, J. (1996). Secularització i pluralisme en la societat catalana d'avui. Barcelona: Institut d'Estudis Catalans.

- (2003). La secularització. Ponència al IV Congrés Català de Sociologia.

FreIRE, P. (1987). L'educació com a pràctica de llibertat. Vic: Eumo.

GERGEN, K. (1991). El yo saturado. Barcelona: Paidós.

GOLEMAN, D. (2002). Intel.ligència emocional. Barcelona: Kairós.

Griera, M.; URGelL, F. (2002). Consumiendo religión. Nuevas formas de espiritualidad entre la población juvenil. Barcelona: Fundació «la Caixa».

HÉRVIEU-LÉGER, D. (1999). Le pèlerin et le converti: La religion en mouvement. París: Flammarion.

JAMESON, F. (1996). Teoría de la postmodernidad. Madrid: Trotta (1991).

VIDAL, F. (2003). «Famílies joves a Europa», a FUNDACIÓ CLARET (2003). Famílies joves: el repte de viure i transmetre l'experiència cristiana. Barcelona: Claret.

WiLlis. P. (1998). Cultura viva. Barcelona: Diputació de Barcelona (1990).

- (1981). «Producción cultural no es lo mismo que reproducción cultural», a AADD (ed.) (1993). Lecturas de antropología para educadores. Madrid: Trotta.

- (1988). Aprendiendo a trabajar. Madrid: Akal. 